\title{
Implications of spatial distribution of rockfall reconstructed by dendrogeomorphological methods
}

\author{
K. Šilhán, T. Pánek, and J. Hradecký \\ Department of Physical Geography and Geoecology, Faculty of Science, University of Ostrava, Ostrava, Czech Republic \\ Correspondence to: K. Šilhán (karel.silhan@osu.cz)
}

Received: 19 September 2012 - Published in Nat. Hazards Earth Syst. Sci. Discuss.: Revised: 9 May 2013 - Accepted: 15 May 2013 - Published: 12 July 2013

\begin{abstract}
Rockfall is a dangerous geomorphological process. The prediction of potentially threatened areas requires thorough reconstruction of spatial rockfall activity. Dendrogeomorphic methods allow precise determination of both temporal and spatial occurrences of rockfall without the necessity of long-term monitoring. At the case-study site of Taraktash, located among southern slopes of the Crimean Mountains, 114 Crimean pine trees (Pinus nigra ssp. pallasiana) were sampled on a talus slope located under a $150 \mathrm{~m}$ high rockwall. Based on their age, the trees were divided into two distinct groups (young and old trees). Considerable disturbance in the age structure of the trees on the talus was probably caused by a series of strong earthquakes. Major differences were identified in the ability of young and old trees to record a rockfall event. We found that in the first decades of their growth, the ability of the studied $P$. nigra to record rockfall events gradually increased. The trees showed the highest sensitivity at the age of 80 to $90 \mathrm{yr}$; after that age their sensitivity gradually decreases. Two indicators were selected for the spatial reconstruction of rockfall events (the number of rockfall events per tree and recurrence interval). The highest activity was identified on the talus using selected indicators.
\end{abstract}

\section{Introduction}

Rockfall represents one of the most hazardous geomorphic processes and causes annually significant economic losses and many fatalities (Gardner, 1983). Therefore, the understanding of rockfall mechanisms together with its spatiotemporal distribution is one of the prerequisites helping to reduce negative effects and introduce the most effective mitiga- tion strategies. As a consequence, rockfall presumably is one of the most intensively studied geomorphic processes within the cliff zone of mountains (Luckman, 1976). Typical factors (and triggers) of accelerated rockfall activity are recurrent freeze-thaw cycles (Matsuoka and Sakai, 1999; Matsuoka, 2008), permafrost melting (Gruber et al., 2004), heavy rainfalls (Schneuwly and Stoffel, 2008) and temperature anomalies (Šilhán et al., 2011). In seismically active areas, the initiation of rockfall is frequently associated with earthquakes causing dynamic loading of slopes (Keefer, 1984; Marzorati et al., 2002). However, in most cases the origin of rockfall is connected with the combination of several factors (Šilhán et al., 2011), which makes it difficult to predict the rockfall events. Recent rockfall studies are therefore oriented mostly at the zonation of rockfall hazards, based either on field monitoring (Matsuoka, 2008) or susceptibility modelling (Frattini et al., 2008). A disadvantage of both approaches is that they require long-term (e.g. $>10 \mathrm{yr}$, Matsuoka, 2008) field monitoring and/or numerous geotechnical and environmental input parameters, whose derivation is usually very difficult (Chiessi et al., 2010).

Important issues concerning spatial distribution of rockfall hazard have recently come from dendrogeomorphic studies (Stoffel et al., 2005a; Stoffel et al., 2011; Trappmann and Stoffel, 2013). This technique has successfully been applied to the spatio-temporal analysis of debris-flow activity (Bollschweiler et al., 2007; Pelfini and Santilli, 2008; Šilhán and Pánek, 2010; Stoffel, 2010), snow avalanches (Butler and Sawyer, 2008; Casteller et al., 2008), landslides (Fantucci and Sorriso-Valvo, 1999; Stefanini, 2004; Lopez-Saez et al., 2012a, b; Šilhán et al., 2013) and gully erosion (Corona et al., 2011; Stoffel et al., 2012). The great advantage of dendrogeomorphic methods is that they allow rapid acquisition of data, 
which is otherwise accessible only by means of long-term field monitoring. By using dendrogeomorphic methods, it is possible to obtain information on the temporal and spatial distribution of rockfall, sometimes even with seasonal precision (Stoffel et al., 2005a). However, when using dendrogeomorphic techniques, it is necessary to bear in mind some limitations, especially those issuing from the limited age of sampled tress and different sensitivity of trees with various ages to geomorphic disturbances.

The main goals of this paper are twofold: (i) to depict the spatial distribution of rockfall activity on a talus slope situated in a seismically active region of the Crimean Mountains (Taraktash, Ukraine), and (ii) to evaluate rockfall-related growth reactions in tree-ring records from distinct age classes of Pinus nigra ssp. pallasiana.

\section{Settings}

The talus slope (centred at $44^{\circ} 29.120^{\prime} \mathrm{N}, 39^{\circ} 5^{\prime} \mathrm{E}$ ) is situated within the southern slopes of the Crimean Mountains (southern Ukraine), just above the agglomeration of Yalta. Southern (coastal) slopes of the Crimean Mountains are heavily affected by various types of slope deformations, which can be attributed to the presence of unstable sedimentary rocks (flysch and carbonates), active seismicity (e.g. $M=6.8$ September 1927 earthquake) and relatively high annual precipitation totals $(>1000 \mathrm{~mm}$ ) (Pánek et al., 2009a,b). The talus slope is part of a wider slope deformation with abundant unstable rock pinnacles, locally known as Taraktash slope failure (Fig. 1c) (Šilhán et al., 2012). The sampling site is situated under a ca. $150 \mathrm{~m}$ high cliff formed by thin-bedded, strongly fractured Jurassic limestones (Šilhán et al., 2012). Active talus cones under the cliff form a ca. $500 \mathrm{~m}$ wide front in the altitudinal range of $880-690 \mathrm{~m}$ a.s.l., which passes in its downslope part to the forest consisting predominantly of P. nigra (Fig. 1c).

\section{Materials and methods}

Detailed GPS geomorphic mapping using aerial photographs was performed at a scale of 1:500 to depict landforms associated with rockfall activity. The position of all P. nigra trees growing on the talus slope was measured as well. Trees were subsequently sampled with Pressler increment borers (max. $40 \times 0.5 \mathrm{~cm}$ ). Four increment cores were taken from each tree: one upslope, one downslope and one from each side of the trunk, at right angles to the slope direction. Trees were sampled at the height of the maximum density of the stem damage (about $0.8 \mathrm{~m}$ ), where their circumference was measured as well. An additional population of 20 P. nigra individuals (as old as possible) growing outside the influence of rockfall and other catastrophic geomorphic processes was sampled for the reconstruction of a local reference chronology (see Fig. 1c for position). These reference trees are pre- sumed to be influenced only by climatic factors. The processing of increment cores was performed in accordance with the standard procedure described by Bräker (2002). Individual steps included drying the samples, sticking them to woody supports, core sanding, counting of tree rings and measuring the widths of rings (to within $0.01 \mathrm{~mm}$ ) using TimeTable and PAST4 software (V.I.A.S., 2005). Finally, samples were cross-dated with the reference chronology in order to identify false or missing tree rings.

The identification of rockfall events was based on known reactions of trees to their damage caused by released rock clasts. These signals were visually identified on the polished surfaces of increment cores. They involved especially abrupt growth suppression (min. $70 \%$ ) as the reaction to the hits of rock clasts, abrupt growth release (min. 200\%) due to the death of an adjacent tree or trees, reaction (compression) wood as a consequence of tilting by large falling rock fragments and formation of callus tissue which is formed during the overgrowing of damaged parts of stems. All of these signatures were summarised for each tree and compared with the reference chronology in order to avoid disturbances not connected with rockfall activity. Regarding the fact that one rockfall-related hit of a particular tree might generate several types of growth disturbances at the same time, a single rockfall event per year was dated for each individual tree (Perret et al., 2006b). Therefore, the number of dated rockfall events should be considered as minimal.

Spatial aspects of rockfall were expressed by (i) the number of rockfall events recorded within individual trees $\left(R_{n}\right)$ and (ii) recurrence interval $\left(R_{i}\right)$.

The recurrence interval (average time period between two successive rockfall events) was calculated as

$R_{i}=\frac{A_{t}}{\mathrm{RE}_{t}}$,

where $A_{t}$ is the age of tree $t$ and $\mathrm{RE}_{t}$ is the number of dated rockfall events recorded in tree $t$. Tree age, $R_{n}$ and $R_{i}$ were then interpolated using software Surfer 8 (Golden Software, 2002). Based on their age, all disturbed trees were divided into two groups: young trees and old trees. The group of young trees consists of trees that started to grow after the long antecedent period void of newly growing trees - that is, after the 1930s (Fig. 2). The two groups were analysed separately.

\section{Results}

\subsection{Dendrogeomorphic analysis}

All trees growing in the upper part of the talus slope below the cliff were sampled in a $\sim 30 \mathrm{~m}$ wide belt (Fig. 1c). We sampled a total of $114 P$. nigra trees with 456 increment cores. The age of the youngest and oldest trees at sampling height is 18 (AD 1991) and 380 (AD 1629) yr. The mean 


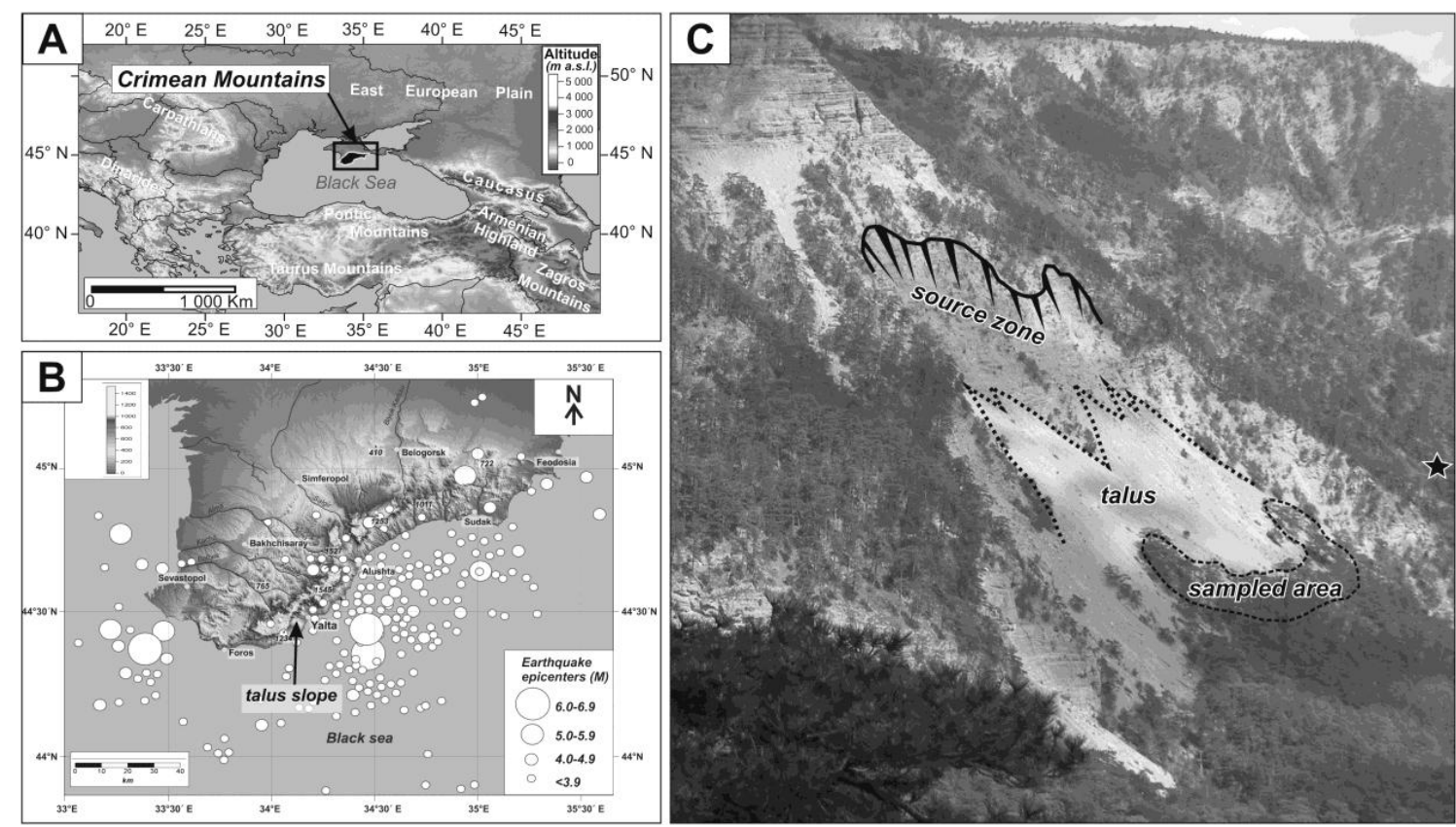

Fig. 1. A - location of the Crimean Mountains. B - location of the talus slope in the vicinity of Yalta and the epicentres of historical earthquakes. $\mathbf{C}$ - detailed view of locality studied (star - position of reference trees).

age of the sampled trees equals $154 \mathrm{yr}$ (stdev: $92.4 \mathrm{yr}$ ). Out of the total of 456 increment cores, 977 growth disturbances were identified associated with rockfall activity. Before sampling, all trees were carefully selected on the basis of detailed visual analysis of their damage in order to exclude other geomorphological processes. Also, growth curves of disturbed trees were compared with the reference chronologies to exclude the effect of climate on growth anomalies. Therefore, it is possible to mark the origin of all identified growth disturbances related to rockfall activity. The most abundant reactions in trees were abrupt growth suppressions with 510 occurrences $(51 \%)$. Abrupt growth release was detected in 172 cases $(18 \%)$, reaction wood in 156 cases $(16 \%)$ and callus tissue in 156 cases (15\%). Regarding the fact that some identical (simultaneous) growth disturbances were detected on several increment cores of the same tree, the number of reconstructed rockfall events was reduced to 703 . The mean stem diameter was $41.6 \mathrm{~cm}$ (stdev: 25.7), whereas minimum and maximum diameters were $6.4 \mathrm{~cm}$ and $102.8 \mathrm{~cm}$.

Field mapping and tree-ring analysis revealed the existence of two generations of trees with distinct ages. The first group, named "young trees", has a mean age of $64 \mathrm{yr}$ ( $n=49$; stdev: $30.1 \mathrm{yr}$; minimum age is 18 and maximum $81 \mathrm{yr}$ ), whereas the second group, named "old trees", has a mean age of $226 \mathrm{yr}(n=65$; stdev: $53.8 \mathrm{yr}$; minimum age is 113 and maximum $380 \mathrm{yr}$ ). The types and frequency of growth disturbances in both groups are displayed in Table 1. As a consequence of the distinct age structure, the two groups of trees were analysed separately.

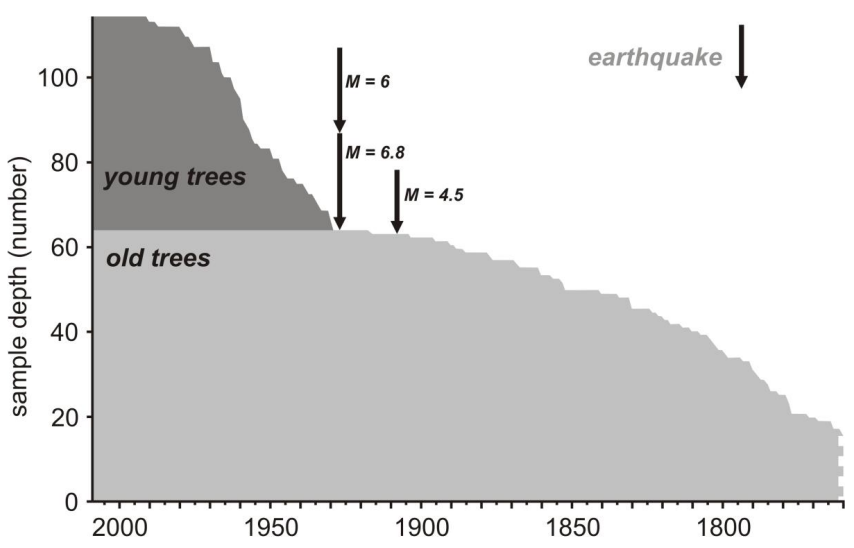

Fig. 2. Time evolution of the number of trees (sample depth SD) and earthquake occurrence $(M>4)$.

The analysis of a potential change in the trees' ability to record a rockfall event with a growing age included the monitoring of an average number of recorded rockfall events in individual decades of the tree age (Fig. 3). Results indicate an increase in the number of recorded events in trees in the first nine decades of their existence. The first decade of tree growth was ignored to avoid effects of juvenile growth. The trees recorded most events when $80-90 \mathrm{yr}$ old. From that age the trees showed a gradual decrease in the number of recorded events. A slightly higher number of events in the first decades of their growth was recorded within the group of young trees $\left(0.67\right.$ rockfall events tree $\left.{ }^{-1}\right)$, as compared to the group of old trees $\left(0.43\right.$ rockfall events tree $\left.{ }^{-1}\right)$. 
Table 1. Dated growth disturbances and number of events from both group of trees.

\begin{tabular}{|c|c|c|c|c|c|c|c|c|}
\hline & & $\begin{array}{c}\text { growth } \\
\text { suppression }\end{array}$ & $\begin{array}{l}\text { growth } \\
\text { release }\end{array}$ & $\begin{array}{l}\text { callus } \\
\text { tissue }\end{array}$ & $\begin{array}{l}\text { reaction } \\
\text { wood }\end{array}$ & total & events & $\begin{array}{l}\text { events } \\
\text { per tree }\end{array}$ \\
\hline \multirow{3}{*}{ 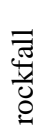 } & young trees & $95(42 \%)$ & $40(18 \%)$ & $25(11 \%)$ & $65(29 \%)$ & 225 & 150 & 2.9 \\
\hline & old trees & $406(54 \%)$ & $132(18 \%)$ & $123(16 \%)$ & $91(12 \%)$ & 752 & 553 & 9.3 \\
\hline & all & $501(51 \%)$ & $172(18 \%)$ & $148(15 \%)$ & $156(16 \%)$ & 977 & 703 & 6.5 \\
\hline
\end{tabular}
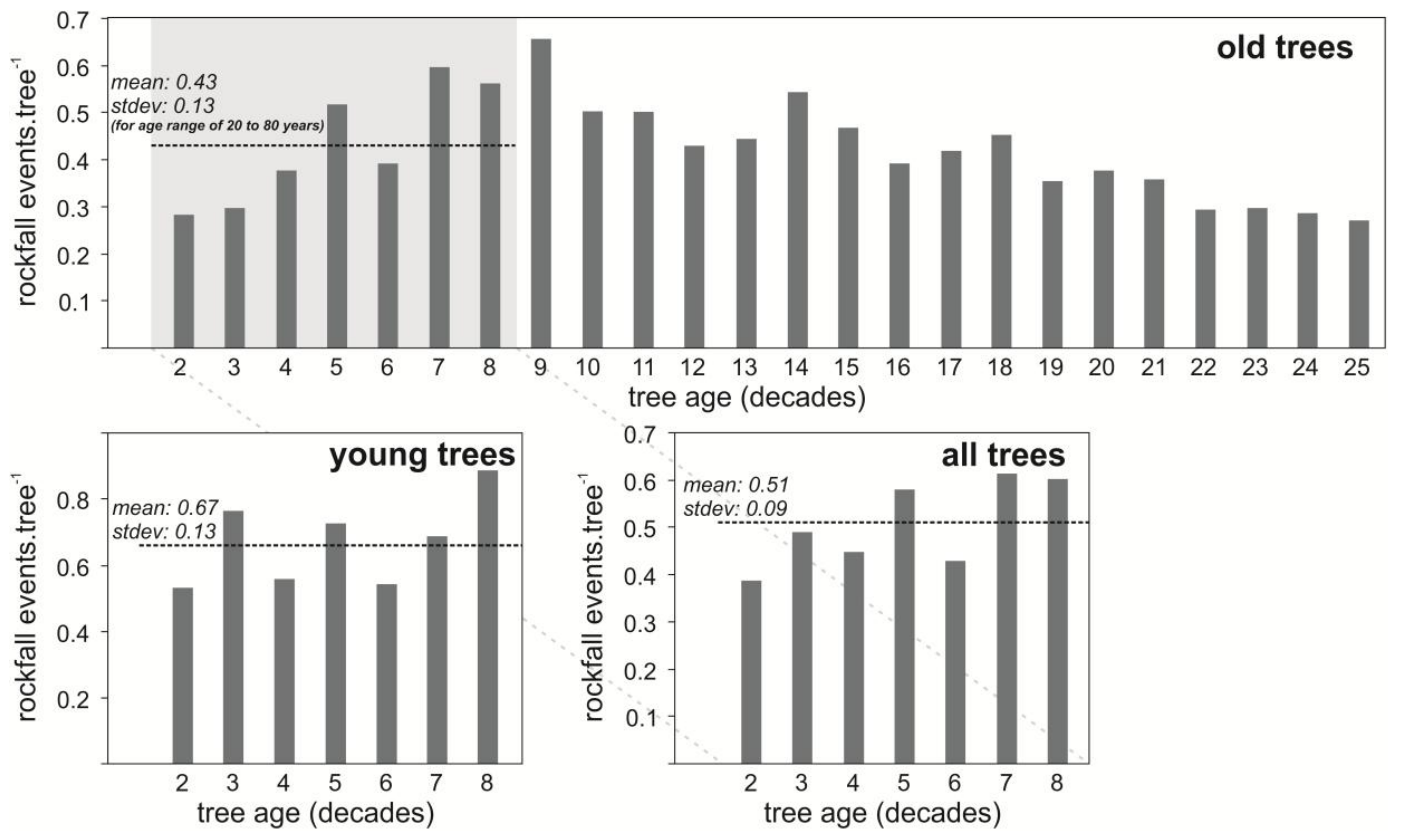

Fig. 3. Evolution of the number of recorded rockfall events per one tree in individual tree age decades.

\subsection{Spatial distribution of tree ages}

The oldest individuals $(\sim 90 \mathrm{yr})$ from the first group (young trees) are concentrated in the central part of the talus slope (Fig. 4). This cluster is enclosed by significantly younger individuals $(\sim 50 \mathrm{yr})$ at its northern and southern margins. In comparison with the young group, the older trees do not tend to create marked spatial clusters (Fig. 4a, b). The spatial distribution of tree ages reveals that the older trees $(>300 \mathrm{yr}$ ) grow in the northern and especially southern fringes of the study site (Fig. 4b). Older trees are rather concentrated in the proximal direction with respect to the orientation of the rock cliff, whereas significantly younger individuals are situated downslope. This pattern is evident in the whole northern part of the site. Below this zone (in the southern part of belt), the youngest trees are concentrated above the old group.

\subsection{Number of rockfall events $\left(R_{n}\right)$}

Among the 703 identified rockfall events, 150 were observed in young and 533 in old trees. The mean number of dated events per sampled tree is 6.2 (stdev: 3.9). Maximum and minimum values per sampled tree are 16 and 1 . Event statistics for both groups of trees are displayed in Table 1. The spatial distribution of the frequency of rockfall events coincides well with the distribution of tree age. As for the young trees, the maximum frequency of events is recorded in the central part of the belt, whereas it decreases towards its northern and southern fringes (Fig. 5a). In the case of the old trees, the highest frequency of events is documented in the northern belt of trees, whereas the lowest frequency is recorded in the central zone of the belt (Fig. 5b). The distribution of rockfall events shows that the largest number of events is recorded in the northern and central parts of the slope. On the other hand, the lowest number of events is identified in the lowermost part of the talus slope, in its distal part situated in the largest distance from the cliff. Generally low numbers of events are also revealed by the trees sampled in the southern part of the studied belt. 


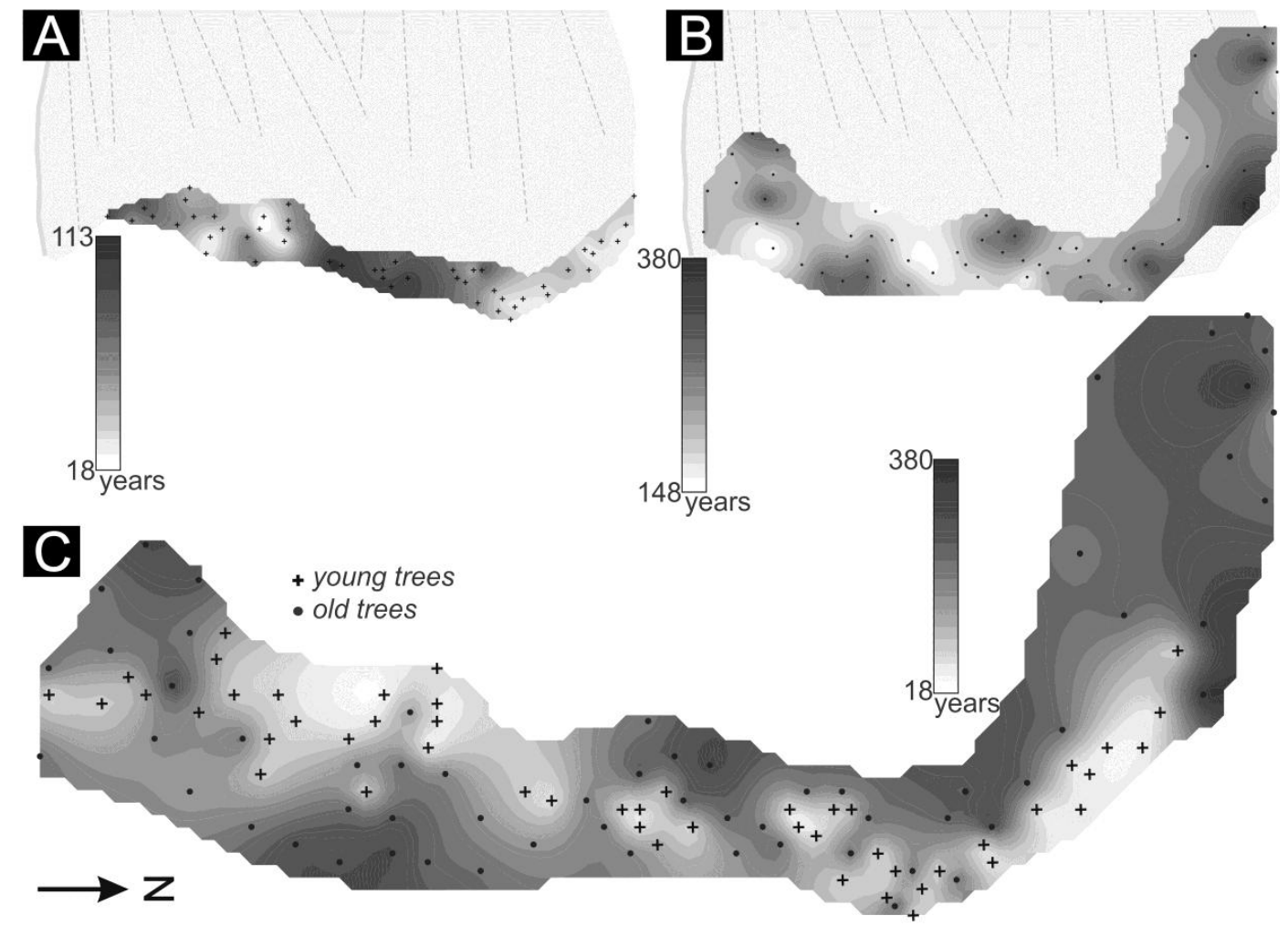

Fig. 4. Spatial distribution of the age structure of sampled trees. $\mathbf{A}$ - young trees, $\mathbf{B}$ - old trees, and $\mathbf{C}$ - all trees.

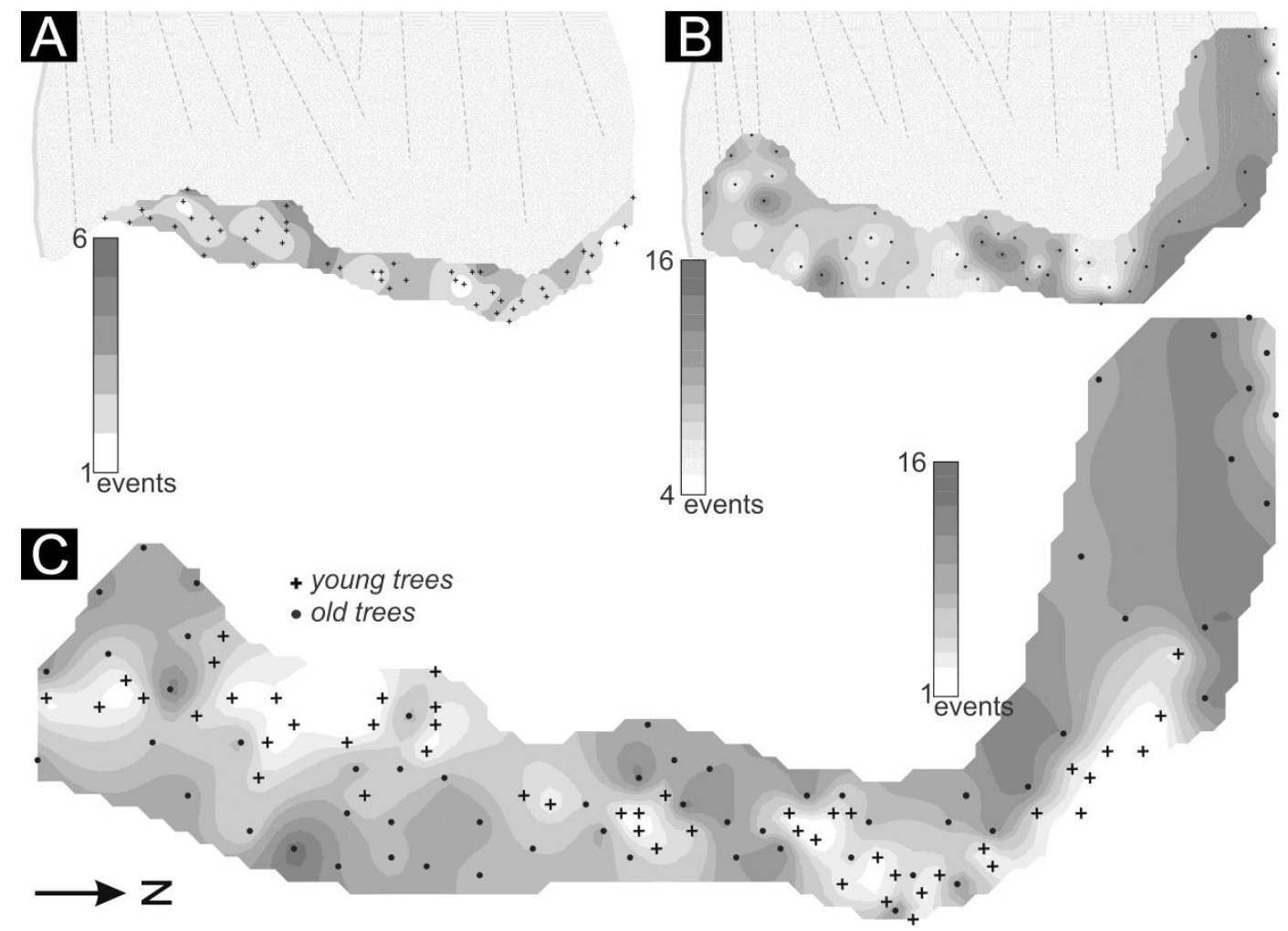

Fig. 5. Spatial distribution of rockfall events recorded within individual trees $\left(R_{n}\right)$. $\mathbf{A}$ - young trees, $\mathbf{B}-$ old trees, and $\mathbf{C}-$ all trees. 


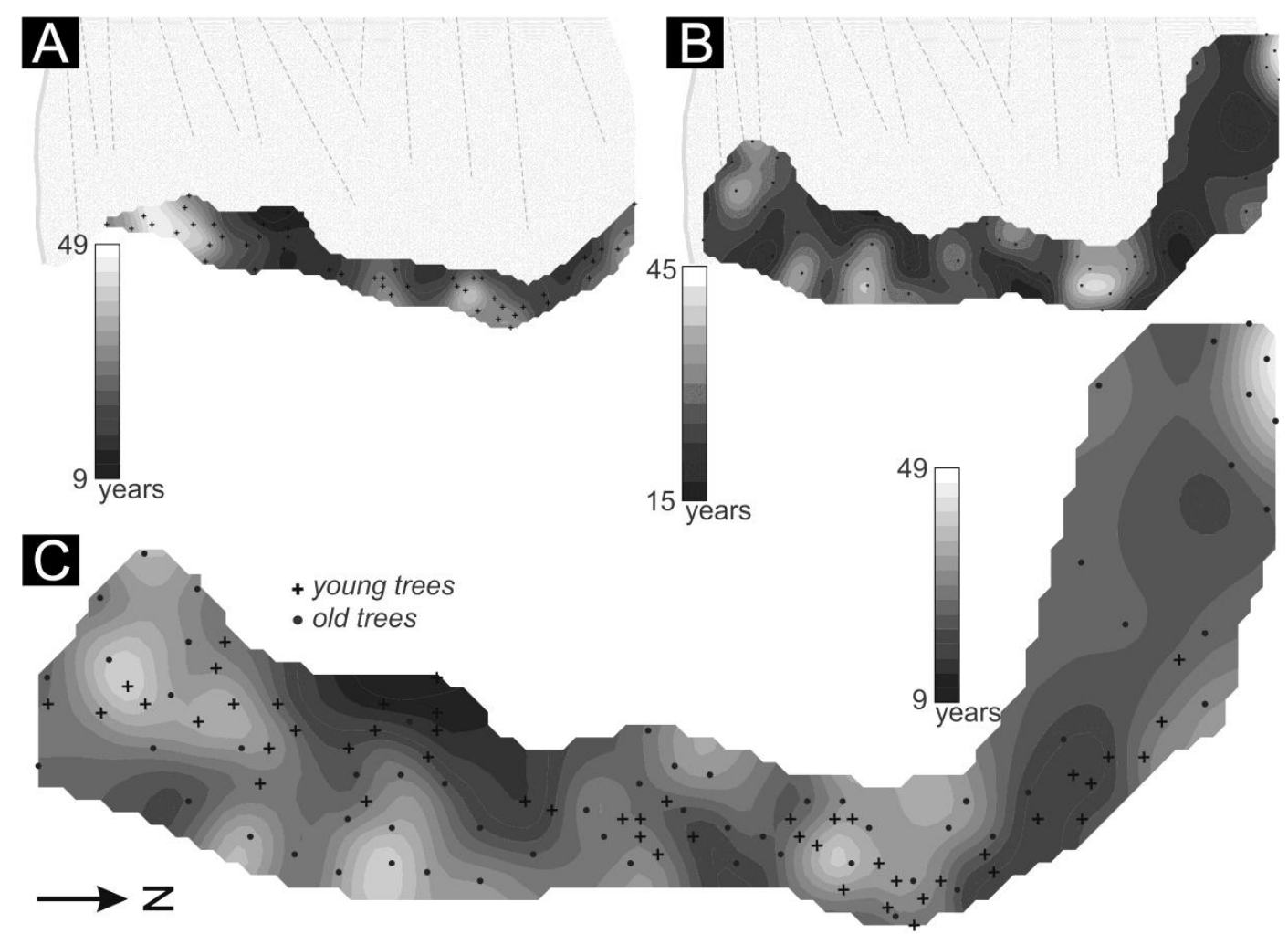

Fig. 6. Spatial distribution of recurrence intervals $\left(R_{i}\right)$. $\mathbf{A}$ - young trees, $\mathbf{B}$ - old trees, and $\mathbf{C}$ - all trees.

\subsection{Recurrence of rockfall events $\left(R_{i}\right)$}

The average time interval passing between two successive hits in a particular tree is $24.6 \mathrm{yr}$ (stdev: $8.8 \mathrm{yr}$ ). The lowest recurrence interval is $9 \mathrm{yr}$, while the highest equals to $49 \mathrm{yr}$. Unlike their old counterparts (mean $R_{i}=26.3 \mathrm{yr}$ ), the young trees show slightly more frequent hits (mean $\left.R_{i}=22.3 \mathrm{yr}\right)$. The longest recurrence interval $\left(R_{i}>40 \mathrm{yr}\right)$ of rockfall events for the young trees is recorded in the southern margin of the belt (Fig. 6a). However, this zone directly borders with the zone of the lowest recurrence interval $\left(R_{i}<15 \mathrm{yr}\right)$. The northern part of the study area is characterised by a slightly higher frequency. The group of the old trees is characterised by alternations of zones with high and low $R_{i}$ (Fig. 6b). A higher frequency of hits is rather visible in the northern part of the belt. If we take into account the combination of both old and young trees (Fig. 6c), it is evident that the trees which are most frequently impacted by falling rock clasts are rather situated in the vicinity of the southern and northern borders of the study site. The northern and southern belts themselves are characterised by a lower frequency of recorded hits.

\section{Discussion}

\subsection{Limits for the reconstruction of rockfall activity using trees of various ages}

Dendrogeomorphic analysis shows that the two identified groups of trees significantly differ in the reactions to rockfallrelated disturbances and their ability to record rockfall events. The number of trees has increased rapidly since the $\sim$ 1930s. This increase, which was preceded by two decades in which the number of trees remained almost unchanged (Fig. 2), can be explained by the occurrence of a moderate earthquake in $1919(M=4.5)$ and strong earthquakes in 1927 ( $M=6$ and $M=6.8$ ) (Nikonov and Sergejev, 1996; USGS, 2010). These events are inferred to have destroyed some of the trees and created new open space for colonisation in the subsequent years, which has manifested itself in the increase of the sample depth (SD) since the 1930s.

Results displayed in Table 1 reveal that the young trees rather react more to the rockfall-related damage by the formation of reaction wood (in comparison to the old trees) than by the production of callus tissue. This is because the younger trees are more flexible and falling rock clasts will rather cause their tilting than damage of their bark (Stoffel and Perret, 2006). The tilting of stems is subsequently compensated by the formation of reaction wood. Moreover, 

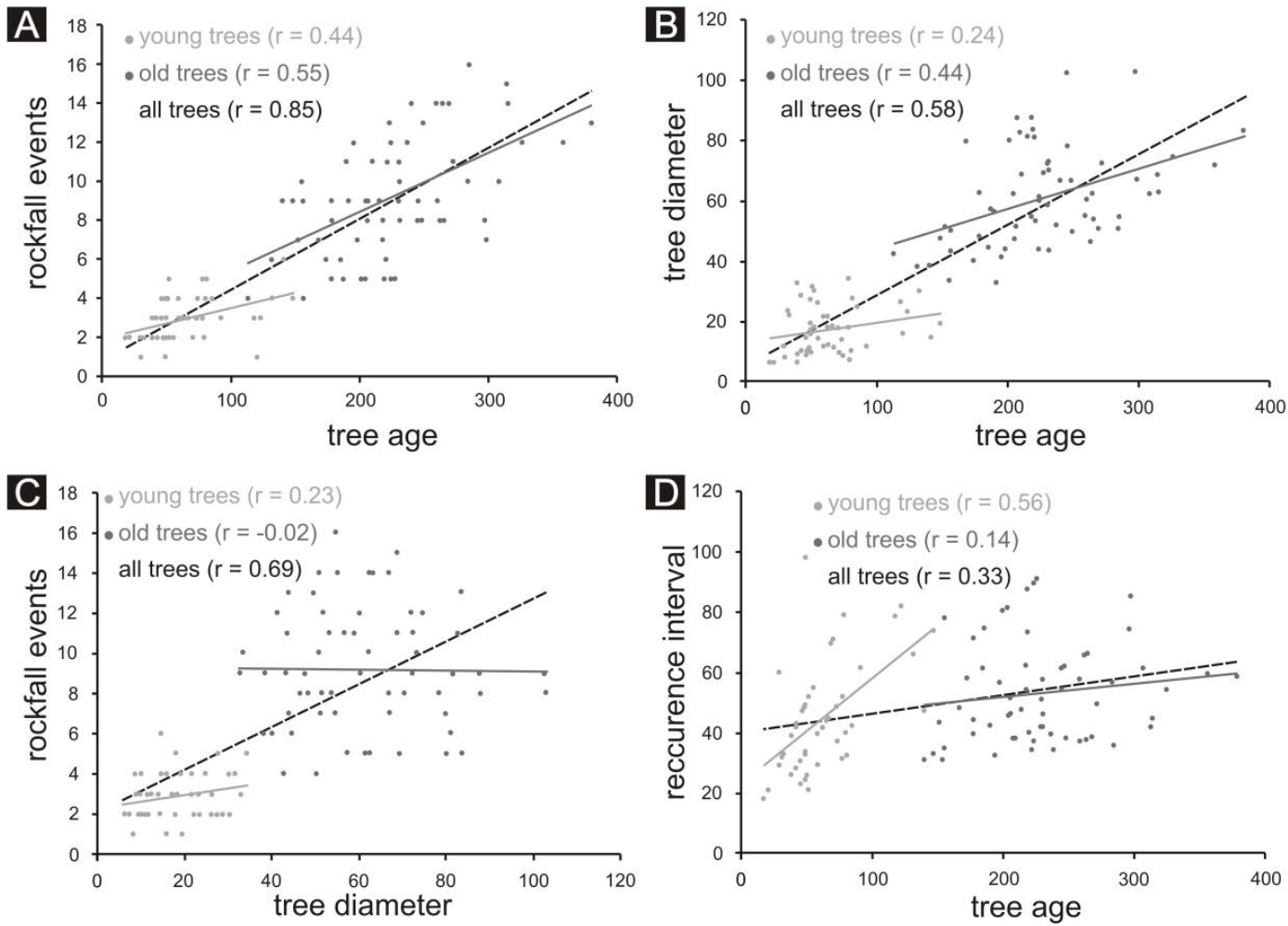

Fig. 7. Graphical relationships between selected parameters of trees and indicators of rockfall activity.

field visual analysis of sampled trees revealed that many trees were under pressure from a high layer of rockfall clasts. Generally, trees tend to react intensively by the formation of compression wood to the lateral pressure of material released during rockfall events (Migoń et al., 2010). The older trees gradually lose their elasticity (Dorren and Berger, 2006) and rockfall-related hits by clasts thus more frequently lead to the formation of scars on their stems. On the contrary, both groups showed almost similar results in the representation of abrupt growth suppression/release. The age of the tree significantly affects the number of rockfall events recorded within its tree-ring structure, which is supported by high correlation $(r=0.85)$ between both variables (Fig. 7). The correlation coefficient is smaller between the age of trees and diameter of their stems $(r=0.58)$. This is due to the fact that trees situated in the zone of active rockfall are influenced by repeated disturbances which lead to their elimination (Stoffel and Perret, 2006; Perret et al., 2006b). Similarly, there is a relatively high correlation between recorded rockfall events and the width of particular tree stems $(r=0.69)$. However, this relationship is not valid for the old trees $(r=-0.02)$. We explain this feature by the existence of thick bark typical of old trees that can be damaged only by voluminous and/or very fast moving rock clasts (Perret et al., 2006a). A fraction of the hits caused by rock clasts are thus not imprinted within the tree-ring archive. That is why it is neces- sary to consider the number of reconstructed rockfall events as a minimal number.

Regarding the efficiency of the reconstruction of rockfall activity, there is a crucial relationship between the age of trees and the $R_{i}$. The younger trees with very thin bark and a higher degree of elasticity display lower $R_{i}$ values which are also characterised by greater variability. In comparison with the old trees, their growth is significantly more sensitive to falling rock clasts. There is generally an indirect relationship between the age of trees and $R_{i}(r=0.33)$ (Fig. 7). A disadvantage of the young trees is that they only cover a very limited time period. Furthermore, their high sensitivity is not only restricted to rockfall but also to other environmental factors (e.g. stress due to snow cover or wind activity). Due to this fact, at least 10 first tree rings should always be excluded from the tree-ring analysis (Stoffel and Bollschweiler, 2008). In the case of the older trees, such influences are much weaker and can be identified using reference chronology. Our data reveal that it is necessary to distinguish between the two populations of trees because of the significantly different capability in the young and the old trees to record rockfall events.

For the first time, this assumption was proven in an exact way on the basis of the analysis of changes in trees' ability to record rockfall events with increasing age (Fig. 3). In the case of $P$. nigra, we also determined the age of trees from 
which they start to be less sensitive to rockfall events ( $90 \mathrm{yr}$ ). Apart from the potential causes mentioned above, declining sensitivity of trees older than $90 \mathrm{yr}$ can also be explained by the necessity to divide the resources for continuously growing trunk surface and branches (Stoffel et al., 2013). In this way, the trees gradually produce thinner rings. Another reason may be the depletion of nutrients within a given territory. However, this question has so far neither been solved nor clarified in scientific studies. If we suppose the identical sensitivity in the first decades of the growth of both groups of trees, then the higher average number of recorded rockfall events by younger trees can be explained by smaller rockfall activity in the past, when compared to the present.

\subsection{Spatial distribution of the rockfall activity}

One of the basic dendrogeomorphic indicators of geomorphic process activity is the spatial distribution of age structures of trees (Pierson, 2007). Regularity of the spatial distribution of young trees and, on the other hand, irregularity of the spatial distribution of old tree ages support the hypothesis that the growth of P. nigra and their colonisation of the talus slope are driven significantly by large-magnitude, seismically induced rockfalls. Major rockfalls are supposed to be responsible for the destruction of a large number of $P$. nigra individuals, enabling subsequent colonisation of openings by young trees. Zones within the talus slope overgrown predominantly by young individuals are assumed to have been affected by large-magnitude rockfall events in the past. On the contrary, parts of the talus colonised by old trees are less prone to major rockfall activity. This means that trees tend to grow older in areas which are less affected by rockfall. Less effective rockfall in such zones enabled establishment and survival of very old trees, which in turn poses a competitive barrier for the colonisation by young trees. Such a situation is observed, e.g. on the absolute north-western margin of the talus slope, where old trees are simultaneously growing in the most proximal part with respect to the position of the cliff face. This evidence suggests generally low activity of rockfall in this place. An interesting composition of the age structure of trees is also evident in the central part of studied talus, where the belt of young trees is situated below the belt of the old trees. Unlike a general assumption, old trees here most probably do not act as a sufficient natural barrier, namely because of their small number and wide spacing. Since a similar effect is observed in the northern part of the talus, it is necessary to consider the aspects of spatial composition of trees.

The spatial distribution of the number of rockfall events $\left(R_{n}\right)$ coincides well with the age structure of trees growing on the talus slope. Older trees have been able to record rockfall events for a much longer period of time, which is a disadvantage for the germination of young trees. Therefore, $R_{n}$ is not a reliable parameter for the application within forests characterised by an irregular age structure of trees. However, it might be suitable for populations of trees with homogenous age structure (e.g. monocultures).

In comparison with $R_{n}$, recurrence interval $\left(R_{i}\right)$, being a typical feature of rockfall activity, is more suitable due to the fact that it eliminates various ages of sampled trees (Stoffel et al., 2005b). Spatial distribution of $R_{i}$ enables a more exact view on the spatial distribution of rockfall activity within the talus slope. Distribution of $R_{i}$ on the Taraktash talus slope supports an assumption that rockfall is more frequent in zones colonised by young trees. Rockfall events here are recorded by tree rings with the highest frequency.

\section{Conclusions}

The spatial distribution of rockfall activity was investigated in on a talus slope beneath a $\sim 150 \mathrm{~m}$ high limestone cliff the southern Crimean Mountains. We identified 703 rockfall events using tree-ring analysis of 114 P. nigra trees. The talus slope is colonised by two generations of trees (young and old), where younger generation is interpreted as a result of the reaction to high-magnitude seismically induced rockfall events. The young trees (max. age $81 \mathrm{yr}$ ) are more sensitive to the rock impacts and thus allow a more detailed reconstruction of rockfall chronologies than do the old trees (min. age $113 \mathrm{yr}$ ). The ability of trees to record rockfall events changes with time. The studied $P$. nigra showed a gradually increasing number of rockfall events tree ${ }^{-1}$ in the first eight decades of the tree age. The highest sensitivity was identified in trees in the range of 80 to $90 \mathrm{yr}$. Starting with the ninth decade, tree sensitivity continuously decreases. Older trees stand for a very sensitive indicator of events in the past, whereas younger trees are able to record very well contemporary activity of rockfall processes. Hence, it is recommended to use trees with different age composition for reliable reconstruction of rockfall chronologies.

The analysis of spatial distribution of the age structure of trees growing on the talus slope reveals possible zones which have been affected by destructive effects of high-magnitude rockfall. Such places are colonised by the youngest trees. This expectation is also supported by the analysis of the average period between two successive hits of a particular tree by a rock clast. The shortest average recurrence intervals are detected just at places with occurrence of the youngest trees. On the contrary, very old trees grow in the zones characterised by low rockfall activity with the longest average recurrence periods.

Acknowledgements. This research was supported by the project of the Czech Science Foundation no. P209/12/0317: "Late Quaternary evolution of the complex gravitational slope deformations on the southern slopes of the Crimean Mountains (Ukraine)". Thanks are also extended to Monika Hradecká for the translation review, and Veronika Komárková, Václav Stacke and Marek Václavek for their assistance in field work. Markus Stoffel and David Keefer are warmly thanked for providing very useful comments. 
Edited by: D. Keefer

Reviewed by: M. Stoffel, J. Corominas, and one anonymous referee

\section{References}

Bollschweiler, M., Stoffel, M., Ehmisch, M., and Monbaron, M.: Reconstructing spatiotemporal patterns of debris-flow activity with dendrogeomorphologic methods, Geomorphology, 87, 337351, doi:10.1016/j.geomorph.2006.10.002, 2007.

Bräker, O. U.: Measuring and data processing in tree-ring research - a methodological introduction, Dendrochronologia, 20, 203216, doi:10.1078/1125-7865-00017, 2002.

Butler, D. R. and Sawyer, C. F.: Dendrogeomorphology and highmagnitude snow avalanches: a review and case study, Nat. Hazards Earth Syst. Sci., 8, 303-309, doi:10.5194/nhess-8-3032008, 2008.

Casteller, A., Christen, M., Villalba, R., Martínez, H., Stöckli, V., Leiva, J. C., and Bartelt, P.: Validating numerical simulations of snow avalanches using dendrochronology: the Cerro Ventana event in Northern Patagonia, Argentina, Nat. Hazards Earth Syst. Sci., 8, 433-443, doi:10.5194/nhess-8-433-2008, 2008.

Chieesi, V., D’Orefice, M., Mugnozza, G. S., Vitale, V., and Cannese, Ch.: Geological, geomechanical and geostatistical assessment of rockfall hazard in San Quirico Village (Abruzzo, Italy), Geomorphology, 119, 147-161, doi:10.1016/j.geomorph.2010.03.010, 2010.

Corona, Ch., Lopez Saez, J., Rovéra, G., Stoffel, M., Astrade, L., and Berger, F.: High resolution, quantitative reconstruction of erosion rates based on anatomical changes in exposed roots at Draix, Alpes de Haute-Provence - critical review of existing approaches and independent quality control of results, Geomorphology, 125, 433-444, doi:10.1016/j.geomorph.2010.10.030, 2011.

Dorren, L. K. A. and Berger, F.: Energy dissipation and stem breakage of trees at dynamic impacts, Tree Physiol., 26, 63-71, doi:10.1093/treephys/26.1.63, 2006.

Fantucci, R. and Sorriso-Valvo, M.: Dendrogeomorphological analysis of a slope near Lago Calabria (Italy), Geomorphology, 30, 165-174, doi:10.1016/S0169-555X(99)00052-5, 1999.

Frattini, P., Crosta, G., Carrara, A., and Agliardi, F.: Assesment of rockfall susceptibility a by integrating statistical and physically-based approaches, Geomorphology, 94, 419-437, doi:10.1016/j.geomorph.2006.10.037, 2008.

Gardner, J. S.: Rockfall frequency and distribution, Z. Geomorphol., 27, 311-324, 1983.

Golden Software.: Surfer Version 8 - Reference Manual, Golden Software Inc., CA, USA, 2002.

Gruber, S., Hoelzle, M., and Haeberli, W.: Permafrost thaw and destabilization of Alpine rock walls in the hot summer of 2003, Geophys. Res. Lett., 31, L13504, doi:10.1029/2004GL020051, 2004.

Keefer, D. K.: Landslides caused by earthquakes, Geol. Soc. Am. Bull., 95, 406-421, doi:10.1130/00167606(1984)95<406:LCBE>2.0.CO;2, 1984,

Lopez-Saez, J., Corono, C., Stoffel, M., Astrade, L., Berger, F., and Malet, J. P.: Dendrogeomorphic reconstruction of past landslide reactivation with seasonal precision: Bois Noir landslide, southern French Alps, Landslides, 9, 189-203, doi:10.1007/s10346011-0284-6, 2012a.
Lopez-Saez, J., Corona, C., Stoffel, M., Schoeneich, P., and Berger, F.: Probability maps of landslide reactivation derived from tree-ring records: Pra Bellon landslide, southern French Alps, Geomorphology, 138, 189-202, doi:10.1016/j.geomorph.2011.08.034, 2012b.

Luckman, B. H.: Rockfalls and rockfall inventory data: some observations from Surprise Valley, Jasper National Park, Earth Surf. Proc. Land., 1, 287-298, doi:10.1002/esp.3290010309, 1976.

Marzorati, S., Luzi, L., and De Amicis, M.: Rock falls induced by earthquakes: a statistical approach, Soil Dyn. Earthq. Eng., 22, 565-577, doi:10.1016/S0267-7261(02)00036-2, 2002.

Matsuoka, N.: Frost weathering and rockwall erosion in the southeastern Swiss Alps: Long-term (19942006) observations, Geomorphology, 99, 353-368, doi:10.1016/j.geomorph.2007.11.013, 2008.

Matsuoka, N. and Sakai, H.: Rockfall activity from an alpine cliff during thawing periods, Geomorphology, 28, 309-328, doi:10.1016/S0169-555X(98)00116-0, 1999.

Migoń, P., Pánek, T., Malik, I., Hradecký, J., Owczarek, P., and Šilhán, K.: Complex landslide terrain in the Kamienne Mountains, Middle Sudetes, SW Poland, Geomorphology, 124, 200214, doi:10.1016/j.geomorph.2010.09.024, 2010.

Nikonov, A. A. and Sergejev, A. P.: Seismogravitacionnyje narusenia reliefa v Krymu při zemletrjasenijach 1927 goda, Geoekologia, 3, 124-133, 1996 (in Russian).

Pánek, T., Danišík, M., Hradecký, J., and Frisch, W.: Morphotectonic evolution of the Crimean mountains (Ukraine) as constrained by apatite fission track data, Terra Nova, 21, 271-278, doi:10.1111/j.1365-3121.2009.00881.x, 2009a.

Pánek, T., Hradecký, J., Šilhán, K., Smolková, V., and Altová, V.: Time constraints for the evolution of a large slope collapse in karstified mountainous terrain of the southwestern Crimean Mountains, Ukraine, Geomorphology, 108, 171-181, doi:10.1016/j.geomorph.2009.01.003, 2009b.

Pelfini, M. and Santilli, M.: Frequency of debris flows and their relation with precipitation. A case study in the Central Alps, Italy, Geomorphology, 101, 721-730, doi:10.1016/j.geomorph.2008.04.002, 2008.

Perret, S., Baumgartner, M., and Kienholz, H.: Inventory and analysis of tree injuries in a rockfall-damaged forest stand, Eur. J. Forest. Res., 125, 101-110, doi:10.1007/s10342-005-0082-6, 2006a.

Perret, S., Stoffel, M., and Kienholz, H.: Spatial and temporal rockfall activity in a forest stand in the Swiss Prealps - a dendrogeomorphological case study, Geomorphology, 74, 219-231, doi:10.1016/j.geomorph.2005.08.009, 2006 .

Pierson, T. C.: Dating young geomorphic surfaces using age of colonizing Douglas fir in southwestern Washington and northwestern Oregon, USA, Earth Surf. Proc. Land., 32, 811-831, 2007.

Schneuwly, D. M. and Stoffel, M.: Tree-ring based reconstruction of the seasonal timing, major events and origin of rockfall on a case-study slope in the Swiss Alps, Nat. Hazards Earth Syst. Sci., 8, 203-211, doi:10.5194/nhess-8-203-2008, 2008.

Šilhán, K. and Pánek, T.: Fossil and recent debris flows in medium-high mountains (Moravskoslezské Beskydy Mts, Czech Republic), Geomorphology, 124, 238-249, doi:10.1016/j.geomorph.2010.03.026, 2010.

Šilhán, K., Brázdil, R., Pánek, T., Dobrovolný, P., Kašičková, L., Tolasz, R., Turský, O., and Václavek, M.: Evaluation of 
meteorological controls of reconstructed rockfall activity in the Czech Flysch Carpathians, Earth Surf. Proc. Land., 36, 18981909, doi:10.1002/esp.2211, 2011.

Šilhán, K., Pánek, T., and Hradecký, J.: Tree-ring analysis in the reconstruction of slope instabilities associated with earthquakes and precipitation (the Crimean Mountains, Ukraine), Geomorphology, 173-174, doi:10.1016/j.geomorph.2012.06.010, 174184, 2012.

Šilhán, K., Pánek, T., Brázdil, R., Havlů, D., Dušek, R., and Hradecký, J.: Dating of bedrock landslide reactivations using dendrogeomorphic techniques: the Mazák landslide, Outer Western Carpathians (Czech Republic), Catena, 104, 1-13, doi:10.1016/j.catena.2012.12.010, 2013.

Stefanini, M. C.: Spatio-temporal analysis of a complex landslide in the Northern Apennines (Italy) by means of dendrochronology, Geomorphology, 63, 191-202, doi:10.1016/j.geomorph.2004.04.003, 2004.

Stoffel, M.: Magnitude-frequency relationships of debris flows A case study based on field surveys and tree-ring records, Geomorphology, 116, 67-76, doi:10.1016/j.geomorph.2009.10.009, 2010.

Stoffel, M. and Bollschweiler, M.: Tree-ring analysis in natural hazards research - an overview, Nat. Hazards Earth Syst. Sci., 8, 187-202, doi:10.5194/nhess-8-187-2008, 2008.

Stoffel, M. and Perret, S.: Reconstructing past rockfall activity with tree rings: some methodological considerations, Dendrochronologia, 24, 1-15, doi:10.1016/j.dendro.2006.04.001, 2006.

Stoffel, M., Lièvre, I., Monbaron, M., and Perret, S.: Seasonal timing of rockfall activity on a forested slope at Täschgufer (Swiss Alps) - a dendrochonological approach, Z. Geomorphol., 49, 89106, 2005a.
Stoffel, M., Schneuwly, D., Bollschweiler, M., Lièvre, I., Delaloye, R., Myint, M., and Monbaron, M.: Analyzing rockfall activity (1600-2002) in a protection forest - a case study using dendrogeomorphology, Geomorphology, 68, 224-241, doi:10.1016/j.geomorph.2004.11.017, 2005b.

Stoffel, M., Bollschweiler, M., Vazquez-Selem, L., Franco-Ramos, O., and Palacios, D.: Dendrogeomorphic dating of rockfalls on low-latitude high-elevation slopes: Rodadero, Iztaccíhuatl volcano, Mexico, Earth Surf. Proc. Land., 36, 1209-1217, doi:10.1002/esp.2146, 2011.

Stoffel, M., Casteller, A., Luckman, B. H., and Villalba, R.: Spatiotemporal analysis of channel wall erosion in ephemeral torrents using tree roots - An example from the Patagonian Andes, Geology, 40, 247-250, doi:10.1130/G32751.1, 2012.

Stoffel, M., Butler, D. R., and Corona, C.: Mass movements and tree rings: A guide to dendrogeomorphic field sampling and dating, Geomorphology, doi:10.1016/j.geomorph.2012.12.017, in press, 2013.

Trappmann, D. and Stoffel, M.: Counting scars on tree stems to assess rockfall hazards: A low effort approach, but how reliable?, Geomorphology, 180-181, 180-186, doi:10.1016/j.geomorph.2012.10.009, 2013.

USGS: Online earthquake catalogue, Earthquake Hazard Program, available at: earthquake.usgs.gov/earthquakes/eqarchives/epic/, last access: June 2013, 2010.

V.I.A.S. (Vienna Institute of Archaeological Science): Time Table, Installation and instruction manual, Rev. 2.1, Vienna, SCIEM, 2005. 